\title{
Perlindungan Hepatotoksisitas Ekstrak Metanol Pegagan Dibanding Vitamin E pada Tikus Model Hepatitis
}

\author{
Putri Vidyaniati, Armaya Ariyoga, Herri S. Satramihardja \\ Bagian Farmakologi \\ Fakultas Kedokteran Universitas Padjadjaran \\ Rumah Sakit Hasan Sadikin, Bandung
}

\begin{abstract}
Abstrak
Tanaman obat pegagan (Centella asiatica Linn) sering digunakan penderita hepatitis sebagai terapi alternatif. Penelitian bertujuan untuk mengetahui efek ekstrak metanol herba pegagan pada tikus model hepatitis yang diinduksi karbon tetraklorida $\left(\mathrm{CCl}_{4}\right)$ dibandingkan dengan vitamin E. Parameter yang diukur adalah kadar serum glutamic pyruvic transaminase (SGPT), malondialdehid (MDA), dan luas nekrosis jaringan hati. Penelitian eksperimental laboratorik dilakukan di Laboratorium Farmakologi Rumah Sakit Hasan Sadikin Bandung, periode Oktober 2009, dengan rancangan acak lengkap terhadap 40 ekor tikus yang dibagi menjadi 8 kelompok. Kadar SGPT serum ditentukan dengan metode enzimatik, MDA diukur dengan metode Wilbur. Luas nekrosis hati dinilai dengan pewarnaan hematoksilin eosin. Hasil penelitian menunjukkan bahwa ekstrak pegagan yang diberikan prainduksi dapat mencegah kenaikan kadar SGPT dan luas nekrosis secara bermakna $(\mathrm{p} \leq 0,05)$, tetapi tidak mencegah kenaikan kadar MDA jaringan hati secara bermakna ( $p>0,05)$. Pascainduksi, ekstrak pegagan menurunkan kadar SGPT, MDA jaringan hati, dan luas nekrosis secara bermakna ( $\mathrm{p} \leq 0,05)$. Semua efek ekstrak pegagan lebih baik daripada vitamin E, sehingga dapat bersifat hepatoprotektif. [MKB. 2010;42(3):101-7].
\end{abstract}

Kata kunci: Malondialdehid jaringan hati, nekrosis, pegagan, serum glutamic pyruvic transaminase

\section{Hepatoprotective Effect of Indian Pennywort Methanol Extract Compare with Vitamin E on Hepatitis Rats Model}

\begin{abstract}
Herbal medicine Indian Pennywort (Centella asiatica Linn) is commonly used as alternative therapy for hepatitis. The aim of this study was to evaluate the effect of Indian Pennywort methanol extract on carbontetrachloride $\left(\mathrm{CCl}_{4}\right)$ induced hepatitis rats model, compared with vitamin E. Parameters used were levels of serum glutamic pyruvic transaminase (SGPT), malondialdehide (MDA), and extent of liver necrosis. Experimental laboratory study was conducted at Pharmacology Laboratory Hasan Sadikin Hospital Bandung, October 2009, with randomized complete design on 40 rats divided into 8 subgroups. The level of SGPT was analyzed by enzymatic method, MDA level was analyzed by Wilbur method. The extent of liver necrosis was analyzed by hematoxylin eosin staining. The results, the extract, if given pre-induction of hepatotoxicity, can significantly prevent the increase of SGPT levels and the extent of necrosis ( $p \leq 0.05$ ), but can't significantly prevent the increase of liver tissue MDA levels $(p>0.05)$. Postinduction, the extract can significantly reduce the SGPT levels, liver tissue MDA levels, and the extent of liver necrosis $(\mathrm{p} \leq 0.05)$. Therefore, effect of the Indian Pennywort extract is better than vitamin E, and can act as hepatoprotector. [MKB.2010;42(3):101-7].
\end{abstract}

Key words: Indian pennywort, liver tissue malondialdehide, necrosis , serum glutamic pyruvic transaminase

Korespondensi: dr. Putri Vidyaniati, Fakultas Kedokteran Universitas Padjadjaran, Bandung, jalan Prof. Dr. Eijkman 38 Bandung 40161, telepon (022) 2032170, mobile 081394224788, e-mail: p.vidyaniati@gmail.com 


\section{Pendahuluan}

Hati adalah organ yang sangat penting untuk mempertahankan hidup karena menjadi pusat metabolisme tubuh. ${ }^{1}$ Kerusakan sel hati dapat berupa nekrosis sehingga enzim yang terkandung di dalamnya akan keluar dan masuk ke peredaran darah. Enzim serum glutamic pyruvic transaminase (SGPT) merupakan enzim yang spesifik untuk evaluasi kelainan hati. ${ }^{2}$ Aktivasi sel Kupffer pada peradangan hati akan menghasilkan radikal bebas. ${ }^{3}$ Radikal bebas dalam jumlah berlebih akan menyebabkan stres oksidatif, yang dapat dilihat dengan pemeriksaan kadar malondialdehid (MDA) dari darah dan jaringan. ${ }^{4}$

Indonesia merupakan negara dengan tingkat endemisitas hepatitis sedang sampai tinggi. Penatalaksanaan hepatitis sampai saat ini belum memuaskan. Berdasarkan pertimbangan ini, beberapa dokter dan penderita mulai memilih terapi alternatif dengan tanaman obat. ${ }^{5}$ Saat ini terbukti ada tanaman obat yang berkhasiat hepatoprotektor, dapat melindungi sel hati dari pengaruh zat toksik yang merusak, bahkan dapat memperbaiki fungsi jaringan hati yang sedang terganggu. ${ }^{1}$ Preparat protektif hati harus mampu melindungi sel hati dengan pemberian sebelum atau saat kerusakan hati. ${ }^{6}$ Suplementasi vitamin E juga telah diteliti sebagai terapi untuk hepatitis B dan C kronik. ${ }^{7}$

Salah satu tanaman obat yang digunakan masyarakat untuk mengobati penyakit hati adalah pegagan/Indian pennywort (Centella asiatica Linn). ${ }^{5}$ Diduga senyawa glikosida triterpenoida atau asiatikosida berperan dalam penyembuhan penyakit. ${ }^{1}$ Penelitian pendahuluan yang dilakukan oleh peneliti mendapatkan dosis uji untuk ekstrak metanol sebesar $200 \mathrm{mg} / \mathrm{kgBB}$.

Penelitian ini bertujuan untuk melihat efek hepatoprotektif ekstrak metanol herba pegagan terhadap sel hati tikus model hepatitis dibanding vitamin E. Pemberian ekstrak dilakukan pra dan pascainduksi hepatotoksisitas karbon tetraklorida $\left(\mathrm{CCl}_{4}\right)$. Indikator yang digunakan adalah kadar SGPT, kadar MDA jaringan hati, dan luas nekrosis jaringan hati.

\section{Metode}

Penelitian eksperimental laboratorik secara acak, dilakukan selama Oktober 2009 di Laboratorium
Farmakologi Rumah Sakit Hasan Sadikin Bandung. Delapan kelompok yang terdiri dari lima tikus diberi perlakuan yang berbeda.

Subjek penelitian adalah 40 ekor tikus jantan galur Wistar berumur 12 minggu, bobot badan antara 200-250 gram yang diperoleh dari Laboratorium Pusat Antar Universitas (PAU) ITB Bandung.

Untuk induksi hepatotoksisitas pada tikus digunakan karbon tetraklorida $\left(\mathrm{CCL}_{4}\right)$, karena dapat menimbulkan gambaran hepatotoksisitas yang khas menyerupai gambaran klasik hepatitis virus namun tanpa HBs antigen. ${ }^{8}$ Nekrosis sentrilobuler difus, degenerasi ballooning sel hati, dan perdarahan akan tampak pada hati tikus satu sampai tiga hari setelah injeksi subkutan $8 \mathrm{~mL} /$ $\mathrm{kgBB} 10 \% \mathrm{CCl}_{4}$ dalam parafin cair, di daerah intraskapular. ${ }^{9}$ Dosis uji ekstrak metanol pegagan adalah $200 \mathrm{mg} / \mathrm{kgBB}$ diperoleh dari penelitian pendahuluan, sedangkan dosis vitamin E sebesar 13,5 IU/kgBB.

Perlindungan terhadap hepatotoksisitas oleh bahan uji dinilai berdasarkan kemampuannya menekan peningkatan aktivitas SGPT, kadar MDA jaringan hati, dan luas nekrosis sel hati. Untuk menilai luas nekrosis sel (\%), dari setiap tikus dibuat 2 preparat dari lobus lateral kiri dan medial kanan. Setiap lobus diambil tiga sayat melintang, dilakukan fiksasi dalam larutan formalin $10 \%$, kemudian dalam parafin, lalu dilakukan pewarnaan dengan hematoksilin-eosin. Kadar MDA jaringan hati diukur dengan metode Wilbur. Kadar SGPT ditentukan dengan memakai metode enzimatik dan hasilnya dibaca dengan spektrofotometri pada panjang gelombang 567 $\mathrm{nm}$. Data diuji dengan analysis of variance dan post hoc test Tukey HSD. Kemaknaan pada derajat kepercayaan $95 \%$ dengan $\mathrm{p} \unlhd 0,05$.

Kelompok I adalah kontrol negatif prainduksi, kadar SGPT, MDA, dan jaringan hati, diperiksa pada hari ke-8. Kelompok II adalah kontrol negatif pascainduksi, pada hari ke-2 diperiksa kadar SGPT, hari ke-4 diperiksa SGPT, MDA, dan jaringan hati. Kelompok III adalah kontrol positif prainduksi, pada hari ke-7 disuntik $\mathrm{Ccl}_{4}$, hari ke-8 diperiksa SGPT, MDA, dan jaringan hati. Kelompok IV adalah kontrol positif pascainduksi, hari pertama disuntik $\mathrm{CCl}_{4}$, hari ke-2 diperiksa SGPT, hari ke-4 diperiksa SGPT, MDA, dan jaringan hati. Kelompok $\mathrm{V}$ adalah perlakuan ekstrak pegagan prainduksi. Diberi ekstraks pegagan dosis $200 \mathrm{mg} / \mathrm{kgBB}$ selama 7 hari. Tiga 
jam kemudian disuntik $\mathrm{CCl}_{4}, 24$ jam kemudian diperiksa SGPT, MDA, dan jaringan hati. Kelompok VI adalah perlakuan ekstraks pegagan pascainduksi. Hari pertama disuntik $\mathrm{CCl}_{4}$, hari ke2 diperiksa SGPT, setelah itu diberi ekstrak pegagan sampai hari ke-4. Tiga jam kemudian diperiksa SGPT, MDA, dan jaringan hati. Kelompok VII adalah perlakuan vitamin E prainduksi, yang diberikan selama tujuh hari. Tiga jam kemudian disuntik $\mathrm{CCl}_{4}$, pada hari ke- 8 diperiksa SGPT, MDA, dan jaringan hati. Kelompok VIII adalah perlakuan vitamin $\mathrm{E}$ pascainduksi. Pada hari pertama disuntik $\mathrm{CCl}_{4}$, hari ke-2 diperiksa SGPT, kemudian diberi vitamin E sampai hari ke-4. Tiga jam kemudian diperiksa SGPT, MDA, dan jaringan hati. Seluruh tikus diperiksa SGPT awal.

\section{Hasil}

Hasil pemeriksaan prainduksi seluruh kelompok dapat dilihat pada Tabel 1 sampai dengan 3 .

Tabel 1 menunjukkan perbedaan bermakna perubahan SGPT awal dan akhir pada semua kelompok $(p=0,001)$. Perubahan SGPT tertinggi terdapat pada kelompok kontrol positif sedangkan terendah pada kelompok kontrol negatif.

Berdasarkan post hoc test terdapat perbedaan bermakna perubahan SGPT antara awal dan akhir pengamatan pada kelompok pegagan dibanding kelompok kontrol positif $(\mathrm{p}=0,026)$, tetapi tidak terdapat perbedaan bermakna pada kelompok $\operatorname{vitamin} \mathrm{E}(\mathrm{p}=0,069)$.
Tabel 2 menunjukkan terdapat perbedaan bermakna MDA $(p=0,023)$ dan luas nekrosis jaringan hati $(p<0,001)$ pada semua kelompok. Kadar MDA jaringan hati tertinggi terdapat pada kelompok kontrol positif $(1150,53 \mathrm{nmol} / \mathrm{mL})$ dan terendah pada kelompok kontrol negatif $(892,70$ $\mathrm{nmol} / \mathrm{mL}$ ).

Berdasarkan post hoc test, terdapat perbedaan bermakna antara kelompok kontrol positif dan negatif ( $p=0,049)$, tetapi tidak terdapat perbedaan bermakna bila dibandingkan dengan kelompok pegagan $(\mathrm{p}=0,152)$ maupun kelompok vitamin $\mathrm{E}$ $(\mathrm{p}=0,997)$.

Pada Tabel 2 dapat dilihat bahwa rata-rata kadar MDA jaringan hati pada perlakuan ekstrak metanol herba pegagan lebih rendah daripada perlakuan vitamin $\mathrm{E}$, tapi perbedaan tersebut belum bermakna secara statistik. Kadar MDA jaringan hati pada kelompok ekstrak metanol herba pegagan lebih mendekati kontrol negatif dan terdapat kecenderungan jauh lebih rendah daripada kontrol positif, namun belum bermakna secara statistik.

Pada Tabel 2 terdapat perbedaan bermakna luas nekrosis sel hati antara semua kelompok $(p<0,001)$. Luas nekrosis sel hati terbesar terdapat pada kelompok kontrol positif $(22,50 \%)$ dan terkecil pada kelompok kontrol negatif $(0,5 \%)$.

Berdasarkan post hoc test terdapat perbedaan bermakna antara kelompok kontrol positif dan negatif $(\mathrm{p}=0,000)$, begitu pula bila dibandingkan dengan kelompok ekstrak pegagan $(\mathrm{p}=0,001)$, maupun kelompok vitamin $\mathrm{E}(\mathrm{p}=0,003)$.

Rata-rata luas nekrosis jaringan hati pada

Tabel 1 Kadar SGPT Prainduksi

\begin{tabular}{|c|c|c|c|c|c|c|c|c|c|}
\hline \multirow{3}{*}{ Kadar SGPT } & \multicolumn{8}{|c|}{ Kelompok } & \multirow{3}{*}{$\mathbf{p}^{*}$} \\
\hline & \multicolumn{2}{|c|}{ Kontrol (-) } & \multicolumn{2}{|c|}{ Kontrol (+) } & \multicolumn{2}{|c|}{ Pegagan } & \multicolumn{2}{|c|}{ Vitamin E } & \\
\hline & Mean & SD & Mean & SD & Mean & SD & Mean & SD & \\
\hline Awal & 69,20 & 11,30 & 76,0 & 10,86 & 73,20 & 13,91 & 75,60 & 11,52 & 0,796 \\
\hline Akhir & 74,00 & 4,41 & 333,80 & 157,98 & 168,60 & 42,93 & 196,80 & 44,28 & 0,002 \\
\hline Perubahan Akhir-Awal & 4,80 & 12,61 & 257,80 & 150,27 & 95,40 & 37,16 & 121,20 & 40,04 & 0,001 \\
\hline
\end{tabular}

Tabel 2 Kadar MDA dan Luas Nekrosis Sel Hati Prainduksi

\begin{tabular}{|c|c|c|c|c|c|c|c|c|c|}
\hline \multirow{3}{*}{ Kadar MDA } & \multicolumn{8}{|c|}{ Kelompok } & \multirow{3}{*}{$\mathbf{p}^{*}$} \\
\hline & \multicolumn{2}{|c|}{ Kontrol (-) } & \multicolumn{2}{|c|}{ Kontrol (+) } & \multicolumn{2}{|c|}{ Pegagan } & \multicolumn{2}{|c|}{ Vitamin E } & \\
\hline & Mean & SD & Mean & SD & Mean & SD & Mean & SD & \\
\hline Jaringan Hati & 892,70 & 26,64 & 1150,53 & 182,75 & 948,64 & 84,69 & 1133,51 & 198,06 & 0,023 \\
\hline $\begin{array}{l}\text { Luas Nekrosis Sel } \\
\text { Hati (\%) }\end{array}$ & 0,50 & 1,11 & 22,50 & 11,72 & 3,50 & 1,36 & 6,00 & 3,79 & $<0,001$ \\
\hline
\end{tabular}


Tabel 3 Kadar SGPT Pascainduksi

\begin{tabular}{|c|c|c|c|c|c|c|c|c|c|}
\hline \multirow{3}{*}{ Kadar SGPT } & \multicolumn{8}{|c|}{ Kelompok } & \multirow{3}{*}{$\mathbf{p}^{*)}$} \\
\hline & \multicolumn{2}{|c|}{ Kontrol (-) } & \multicolumn{2}{|c|}{ Kontrol (+) } & \multicolumn{2}{|c|}{ Pegagan } & \multicolumn{2}{|c|}{ Vitamin E } & \\
\hline & Mean & SD & Mean & SD & Mean & SD & Mean & SD & \\
\hline Awal & 67,20 & 13,53 & 68,20 & 11,75 & 68,40 & 12,34 & 68,30 & 12,70 & 0,998 \\
\hline Hari ke-2 & 67,40 & 9,63 & 253,80 & 146,00 & 286,80 & 141,78 & 178,20 & 43,89 & 0,020 \\
\hline Akhir & 64,60 & 8,62 & 231,00 & 126,61 & 68,60 & 12,36 & 92,80 & 25,60 & 0,003 \\
\hline Perubahan akhir-hari ke-2 & 2,80 & 9,04 & 22,80 & 26,10 & 218,20 & 144,91 & 85,40 & 46,74 & 0,002 \\
\hline
\end{tabular}

${ }^{\text {*) ANOVA (Analysis of varians) }}$

Tabel 4 Kadar MDA dan Luas Nekrosis Hati Pascainduksi

\begin{tabular}{|c|c|c|c|c|c|c|c|c|c|}
\hline \multirow{3}{*}{ Kadar MDA } & \multicolumn{8}{|c|}{ Kelompok } & \multirow{3}{*}{ Nilai $\left.p^{*}\right)$} \\
\hline & \multicolumn{2}{|c|}{ Kontrol (-) } & \multicolumn{2}{|c|}{ Kontrol (+) } & \multicolumn{2}{|c|}{ Pegagan } & \multicolumn{2}{|c|}{ Vitamin E } & \\
\hline & Mean & SD & Mean & SD & Mean & SD & Mean & SD & \\
\hline Jaringan Hati & 757,24 & 92,71 & 1297,24 & 220,97 & 704,48 & 64,54 & 912,41 & 83,12 & $<0,001$ \\
\hline $\begin{array}{l}\text { Luas Nekrosis Sel } \\
\text { Hati }(\%)\end{array}$ & 0,00 & 0,00 & 46,00 & 19,49 & 8,00 & 4,47 & 34,00 & 15,16 & $<0,001$ \\
\hline
\end{tabular}

kelompok ekstrak pegagan lebih rendah daripada vitamin E, walaupun perbedaan tidak bermakna.

Pada Tabel 3 terdapat perbedaan bermakna perubahan SGPT antara akhir pengamatan dan pascainduksi $\mathrm{CCl}_{4}(\mathrm{p}=0,002)$. Penurunan SGPT tertinggi dialami oleh kelompok pegagan $(218,20$ $\mu / L)$ dan terendah kelompok kontrol negatif $(2,80$ $\mu / \mathrm{L})$.

Berdasarkan post hoc test terdapat perbedaan bermakna perubahan SGPT di akhir pengamatan dengan hari ke-2 (pascainduksi $\mathrm{CCl}_{4}$ ) antara kelompok ekstrak pegagan dibandingkan dengan kelompok kontrol positif $(\mathrm{p}=0,005)$, namun tidak demikian dengan vitamin $\mathrm{E}(\mathrm{p}=0,558)$.

Pada tabel 3 dapat dilihat bahwa rata-rata penurunan kadar SGPT pada kelompok ekstrak pegagan lebih tinggi secara bermakna daripada vitamin E. Hasil tersebut menunjukkan bahwa ekstrak pegagan menurunkan kadar SGPT secara bermakna pascainduksi. Vitamin E menurunkan kadar SGPT, tetapi tidak bermakna.

Berdasarkan Tabel 4 terdapat perbedaan bermakna MDA jaringan hati pascainduksi antara semua kelompok $(\mathrm{p}<0,001)$. Malondialdehid jaringan hati tertinggi terdapat pada kelompok kontrol positif $(1297,24 \mathrm{nmol} / \mathrm{mL})$ dan terendah pada kontrol negatif $(757,24 \mathrm{nmol} / \mathrm{mL})$.

Berdasarkan post hoc test, terdapat perbedaan bermakna MDA jaringan hati antara kelompok ekstrak pegagan dan kontrol positif $(\mathrm{p}=0,000)$, begitu juga dibanding kelompok vitamin $\mathrm{E}$ $(\mathrm{p}=0,001)$ dan kontrol negatif $(\mathrm{p}=0,000)$.
Pada Tabel 4 rata-rata MDA jaringan hati kelompok pegagan lebih rendah daripada vitamin E, walaupun hal tersebut tidak bermakna.

Pada Tabel 4 terdapat perbedaan bermakna luas nekrosis sel hati antara semua kelompok $(p<0,001)$. Luas nekrosis sel hati terbesar pada kelompok kontrol positif $(46,00 \%)$ dan tidak terlihat nekrosis pada kelompok kontrol negatif.

Berdasarkan post hoc test, terdapat perbedaan luas nekrosis sel hati secara bermakna antara kelompok kontrol positif dan kontrol negatif ( $\mathrm{p}=0,000$ ), begitu pula bila dibandingkan dengan kelompok ekstrak pegagan $(p=0,001)$, tetapi tidak demikian dengan kelompok vitamin $\mathrm{E}(\mathrm{p}=0,454)$.

Pada Tabel 4 rata-rata luas nekrosis sel hati kelompok ekstrak pegagan lebih rendah secara bermakna daripada vitamin E. Hasil tersebut menunjukkan, ekstrak pegagan menurunkan luas nekrosis sel hati secara bermakna pascainduksi. Begitu pula vitamin E menurunkan luas nekrosis sel hati, tetapi tidak bermakna.

Ekstrak pegagan diuji lebih lanjut di PAU ITB untuk melihat kandungannya, hasil sebagai berikut: alkaloid (positif 0,46\%), flavonoid (positif $0,08 \%$ ), kuinon (negatif), tanin (positif $5 \%$ ), triterpenoid (positif 2,66\%).

\section{Pembahasan}

Karbon tetraklorida menghasilkan $\mathrm{CCl}_{3}, \mathrm{Cl}$, dan $\mathrm{CHCl}_{3}$ yang berperan sebagai radikal bebas yang 
dapat menyebabkan keadaan stres oksidatif. Stres oksidatif menimbulkan peroksidasi lipid yang menyebabkan kerusakan membran dan organel sel dengan perubahan morfologi dan biokimia, diikuti gangguan fungsi dan kematian sel hati. ${ }^{10}$

Pada metode prainduksi, ekstrak pegagan mencegah kenaikan SGPT secara bermakna, begitu pula vitamin E, tetapi tidak bermakna. Hal ini dapat terjadi karena kandungan asiatikosid pegagan dan vitamin E sebagai antioksidan. ${ }^{11}$ Aksi utama vitamin $\mathrm{E}$ menghentikan reaksi berantai radikal bebas. ${ }^{12}$ Vitamin $\mathrm{E}$ sebagai antioksidan mengikat radikal bebas yang dihasilkan $\mathrm{CCl}_{4}$ sehingga menghambat stres oksidatif berlebih pada membran sel dan kenaikan SGPT. ${ }^{13}$ Efek ekstrak pegagan lebih baik dibanding vitamin $\mathrm{E}$ dalam menghambat kenaikan SGPT prainduksi. Hal ini dapat disebabkan kandungan lain seperti tanin dan flavonoid dalam ekstrak pegagan yang sinergis terhadap asiatikosid dalam melindungi sel hati. ${ }^{14}$

Pada metode pascainduksi, ekstrak pegagan dapat menurunkan SGPT secara bermakna, demikian pula vitamin E tetapi tidak bermakna. $\mathrm{Hal}$ ini disebabkan karena pada pegagan terdapat lebih dari satu efek farmakologis, komplementer dan/atau sinergisme dalam komponen bioaktif tanaman obat. ${ }^{14}$ Antioksidan dapat melawan stres oksidatif akibat penurunan SGPT. ${ }^{13}$

Peroksidasi lipid membran menghasilkan MDA sebagai produk akhir. Antioksidan dapat mencegah terjadinya stres oksidatif sehingga menghambat peroksidasi lipid dan tidak terjadi peningkatan MDA. ${ }^{12}$

Nilai MDA jaringan hati prainduksi pada kelompok ekstrak pegagan lebih mendekati kelompok kontrol negatif dan cenderung lebih rendah dibanding kelompok kontrol positif, tetapi tidak bermakna. Nilai MDA pada kelompok vitamin E lebih mendekati kelompok kontrol positif dan cenderung lebih tinggi dibanding kelompok kontrol negatif, tetapi tidak bermakna. Ekstrak pegagan maupun vitamin $\mathrm{E}$ belum dapat mencegah kenaikan kadar MDA jaringan hati. Hal ini mungkin karena kerusakan yang terjadi akibat peroksidasi lipid terlalu besar (seluruh bagian sel), bukan hanya pada membran sel hepatosit saja. Peroksidasi lipid mampu menyebabkan destruksi fosfolipid membran sel, seperti membran plasma bagian luar dan membran organel intraselular, menyebabkan hilangnya integritas membran. ${ }^{16}$ Kemungkinan lain karena adanya pembentukan zat yang tidak berhubungan dengan lipid tetapi mirip dengan MDA dan juga reaktif terhadap thiobarbituric acid (TBA) sehingga kadar MDA meningkat. Thiobarbituric acid dapat bereaksi dengan senyawa lain yang mengandung karbonil. ${ }^{15}$ Dosis vitamin E yang digunakan mungkin lebih kecil dari dosis efektif yang menghambat kenaikan MDA jaringan hati, sehingga hasilnya kurang optimal.

Antioksidan merupakan zat yang menetralisir radikal bebas dan bekerja bertahap (preventif, intersepsi, dan perbaikan). Antioksidan preventif dapat menghentikan pembentukan reactive oxygen species (ROS), di dalamnya termasuk super oxide dysmutase (SOD) dan katalase. Tahap intersepsi terutama melalui penangkapan radikal bebas yang dilakukan oleh vitamin $\mathrm{C}$ dan $\mathrm{E}$, glutation, karotenoid, flavonoid, dan sebagainya. Pada tahap perbaikan dan rekonstitusi, yang terlibat terutama enzim-enzim perbaikan. Vitamin E berfungsi sebagai antioksidan pemutus reaksi berantai yang mencegah propagasi reaksi radikal bebas di semua membran sel. ${ }^{16}$ Belum diketahui pasti pada tahap mana asiatikosida bekerja sebagai antioksidan. Flavonoid, bekerja pada tahap yang sama dengan vitamin $\mathrm{E}$.

Kadar MDA jaringan hati pascainduksi, pada kelompok ekstrak pegagan maupun vitamin $\mathrm{E}$ menunjukkan perbedaan tidak bermakna dengan kontrol negatif, tetapi berbeda bermakna dengan kontrol positif. Artinya pada kelompok pegagan dan vitamin $\mathrm{E}$, stres oksidatif akibat induksi $\mathrm{CCl}_{4}$ dapat dilawan oleh antioksidan asiatikosida dan vitamin E. Ekstrak pegagan lebih baik dari vitamin E dalam menurunkan MDA jaringan hati. Hasil penelitian ini menunjukkan kandungan antioksidan pada ekstrak pegagan dan vitamin $\mathrm{E}$ bekerja lebih baik setelah timbulnya kerusakan hati dibanding sebelumnya.

Perubahan histologi spesifik akibat $\mathrm{CCl}_{4}$ berupa nekrosis sentrilobuler, degenerasi lemak, apoptosis sel, dan vakuolisasi. ${ }^{17}$ Antioksidan juga dapat berefek hepatoprotektif dengan mengikat prooksidan yang dihasilkan oleh $\mathrm{CCl}_{4} \cdot{ }^{10}$

Luas nekrosis sel hati prainduksi kelompok ekstrak pegagan dan vitamin E menunjukkan perbedaan bermakna dibanding kontrol positif. Artinya pada kelompok pegagan dan vitamin E, stres oksidatif pada membran sel akibat induksi $\mathrm{CCl}_{4}$ dapat dicegah oleh asiatikosida dan vitamin E. Efek ekstrak pegagan lebih baik dari vitamin $\mathrm{E}$ dalam mencegah luasnya nekrosis jaringan hati. 
Ekstrak pegagan menurunkan luas nekrosis jaringan hati pascainduksi secara bermakna, demikian juga dengan vitamin $\mathrm{E}$, namun tidak bermakna, jadi efek ekstrak pegagan lebih baik dari vitamin E. Efek ekstrak pegagan terhadap nekrosis jaringan hati sejalan dengan kadar SGPT karena mekanisme enzim akan keluar jika sel hati mengalami perubahan permeabilitas membran. Serum glutamic pyruvic transaminase di dalam sel hati akan keluar dan masuk ke dalam peredaran darah. ${ }^{2}$ Efek ekstrak pegagan mencegah kenaikan SGPT dan mencegah nekrosis jaringan hati.

Dari uraian di atas, ekstrak pegagan dapat mencegah kenaikan SGPT dan luas nekrosis jaringan hati prainduksi $\mathrm{CCl}_{4}$ secara bermakna. Ekstrak pegagan juga dapat menurunkan SGPT, MDA, dan luas nekrosis jaringan hati secara bermakna pascainduksi $\mathrm{CCl}_{4}$, tetapi belum dapat menurunkan MDA secara bermakna prainduksi.

Penelitian ini memeriksa kandungan ekstrak pegagan lebih lanjut. Pegagan mengandung tidak $<2 \%$ glikosida estertriterpen, asiatikosida, dan madekassosida. ${ }^{13}$ Pegagan yang digunakan pada penelitian ini mengandung 2,66\% triterpenoid. Kandungan pegagan lainnya antara lain alkaloid, flavonoid, dan tanin. Satu tanaman memiliki lebih dari satu efek farmakologi karena adanya efek komplementer dan/atau sinergisme dalam komponen bioaktif tanaman obat. ${ }^{14}$ Aktivitas antioksidatif tanin antara lain menghambat pembentukan oksigen aktif (dapat menyebabkan oksidasi), peroksidasi lipid di mitokondria dan mikrosom hepar tikus, reduksi kandungan lipid peroksidasi dalam serum dan hepar tikus, serta aktivitas antihepatotoksik pada kultur primer hepatosit tikus. ${ }^{19}$ Tanin juga berperan sebagai kelator ion logam yang dapat mengubah potensial redoks dari logam, atau mencegah partisipasinya dalam reaksi redoks. ${ }^{20}$ Flavonoid merupakan bagian dari polifenol yang berfungsi sebagai antioksidan primer, kelator, dan scavenger anion superoksida. Mekanisme proteksi antioksidan fenolik sebagai scavenger radikal peroksida lebih efektif selama tahap propagasi oksidasi, dengan menghambat pembentukan hidroperoksida, sehingga menghentikan reaksi rantai. ${ }^{13}$

Simpulan ekstrak pegagan yang mengandung asiatikosida sebagai antioksidan berpotensi hepatoprotektif terhadap hati tikus model hepatitis, dan lebih baik dibandingkan dengan vitamin E. Efek hepatoprotektif timbul karena efek antioksidan.
Obat herbal Indonesia digunakan berdasarkan praktik empiris untuk preventif, promosi, kuratif, dan kosmetik. ${ }^{18}$ Hasil penelitian memperlihatkan bahwa efek ekstrak pegagan pascainduksi lebih baik daripada prainduksi. Hal ini mendukung fenomena masyarakat yang cenderung memakai pegagan untuk mengobati gangguan hati daripada mencegahnya.

\section{Daftar Pustaka}

1. Dalimartha S. Fisiologi hati. Dalam: Badawi A, penyunting. Obat tradisional penyakit hati: Seri agrisehat, ramuan tradisional untuk pengobatan hepatitis. Jakarta: Penebar Swadaya; 2006. hlm. 85-6.

2. Pratt DS, Kaplan MM. Evaluation of liver function. Dalam: Kasper DL, Braunwald E, Hauser S, Longo D, Jameson JL, Fauci AS, penyunting. Harrison's principles of internal medicine. Edisi ke-16. New York: McGraw-Hill Medical Publishing Division; 2005. hlm. 1813.

3. Gunawan H, Lukita-Atmadja W. Daya antihepatotoksik kurkuminoid terhadap nekrosis hepatosit dan aktivitas sel Kupffer/makrofag pada proses peradangan hati yang diinduksi dengan karbon tetraklorida. MKB. 1997;29(1):1-8.

4. Kadiiska MB, Gladen BC, Baird DD, Germolec D, Graham LB, Parker CE, et al. Biomarkers of oxidative Stress Study II: are oxidation products of lipids, proteins, and DNA markers of $\mathrm{CCl}_{4}$ poisoning. Free Radic Biol Med. 2005;38(6):698710.

5. Afifah E, Lentera T. Sehat dengan ramuan tradisional, tanaman obat untuk mengatasi hepatitis. Jakarta: PT AgroMedia Pustaka; 2005.

6. Kuntz E, Kuntz HD. Principles and practice. Germany: Springer Medizin Verlag Heidelberg; 2002.

7. Andreone P, Gramonzi A, Bernardi M. Vitamin E for chronic hepatitis. Annals Inter Med. 1998;128 (2):156-7.

8. Kelompok Kerja Ilmiah. Hepatoprotektor. Dalam: Departemen Kesehatan RI, peyunting. Pedoman pengujian dan pengembangan fitofarmakapenapisan farmakologi, pengujian fitokimia dan pengujian klinik. Jakarta: Yayasan Pengembangan Obat Bahan Alam Phyto Medica; 1993. hlm. 69-71.

9. Theophilea D, Emerya TD, Desirea DDP, Veroniqueb PB, Njikama N. Effects of alafia multiflora stapf on lipid peroxidation and antioxidant enzyme status in carbon tetrachloridetreated rats. Pharmacologyonline. 2006;2:76-89.

10. Young LS, Woodside JV. Antioxidant: health and 
disease. J Clin Pathol [serial online] 2001;(54): (diunduh 15 Juli 2009). Tersedia dari: http://jcp. bmijournals.com.

11. Derrida M. Gotu Kola Centella asiatica, the goddess of supreme wisdom, phytochemicals, constituents and mechanism of Gotu Kola. 2007 (diunduh 5 Juli 2009). Tersedia dari: http://www. mdidea.com/products/herbextract/gotukola/data. html.

12. Ibrahim W, Lee U, Yeh C, Szabo J, Bruckner G, Chow CK. Oxidative stress and antioxidant status in mouse liver: effects of dietary lipid, vitamin $\mathrm{E}$ and iron. J Nutrit. 1997;127(7):1401-6.

13. Saniah Bte Kormin. The effect of heat processing on triterpene glycosides and antioxidant activity of herbal pegagan (Centella asiatica L. Urban) drink (thesis). Malaysia: Faculty of Chemical and Natural Resources Engineering, Universiti Teknologi Malaysia; 2005.

14. Katno, Pramono S. Tingkat manfaat dan keamanan tanaman obat dan obat tradisional. Yogyakarta: Balai Penelitian Tanaman Obat Tawangmangu Universitas Gadjah Mada; 2005.

15. Devasagayam TPA, Tilak JC, Boloor KK, Sane KS, Ghaskadbi SS, Lele RD. Free radicals and antioxidant in human health: current status and future prospects. JAPI. 2004;52:794-804.

16. Tukozkan N, Erdamar H, Seven I. Measurement of total malondialdehyde in plasma and tissue by high-performance liquid chromatography and thiobarbituric acid assay. Firat Tip Dergisi. 2006; 11(2):88-92.

17. Ghany M, Hoofnagle JH. Approach to the patient with liver disease. Dalam: Kasper DL, Braunwald E, Hauser S, Longo D, Jameson JL, Fauci AS, penyunting. Harrison's principles of internal medicine. Edisi ke-16. New York: McGraw-Hill Medical Publishing Division; 2005. hlm. 1808-13.

18. Hanafi M, Nina A, Fadia Z, Nurbaiti. Indonesian country report on traditional medicine. slides 2005 (diunduh 2 Januari 2010). Tersedia dari: http:// www.niscair.res.in/conclave/downloadables/Plen ary $\% 20$ Session $\% 203 /$ Country $\% 20$ Papers $/ 3 . \% 20$ Indonesia.pdf

19. Hernawan UE, Setyawan AD. Review: ellagitanin; biosintesis, isolasi, dan aktivitas biologi. Biofarmasi. 2003;1(1):25-38.

20. Hagerman AE. Tannin chemistry: biological activities of tannins. 2002 (diunduh 2 Januari 2010). Tersedia dari: http://www.users.muohio. edu/hagermae/tannin.pdf 